AL IBTIDA: JURNAL PENDIDIKAN GURU MI (2019) Vol 6 (1): 124-133

DOI: http://dx.doi.org/ 10.24235/al.ibtida.snj.v6i1.4186

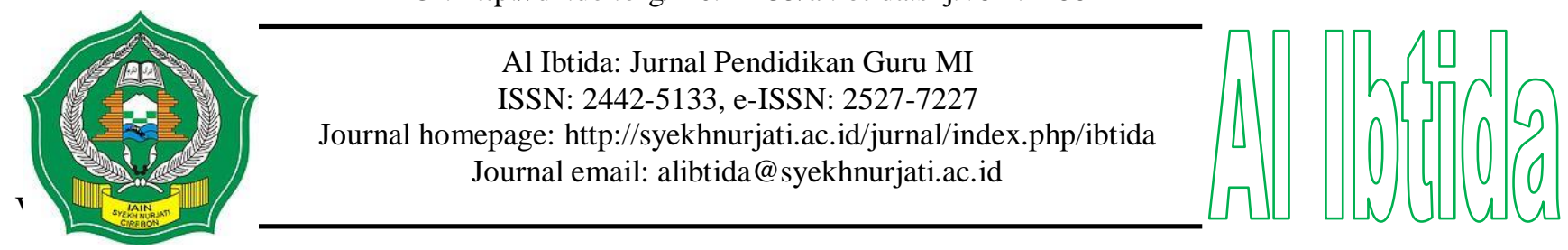

\title{
The Effect of Crossword Puzzle Application on The Students' Learning Motivation in Science Learning
}

\section{Tati Nurhayati*}

*Department of Madrasah Ibtidaiyah Teacher Education, Faculty of Tarbiyah and Teacher Training, IAIN Syekh Nurjati Cirebon

Email: tatinurhayati674@gmail.com

\section{Dwi Anita Alfiani**}

**Department of Madrasah Ibtidaiyah Teacher Education, Faculty of Tarbiyah and Teacher Training,

IAIN Syekh Nurjati Cirebon

Email: deamers77@gmail.com

\section{Dewi Setiani****}

***Department of Madrasah Ibtidaiyah Teacher Education, Faculty of Tarbiyah and Teacher Training, IAIN Syekh Nurjati Cirebon

Email: dewisetiani376@gmail.com

Received: April 26 ${ }^{\text {th }}, 2019$. Accepted: June 24 ${ }^{\text {th }}, 2019$. Published: June $30^{\text {th }}, 2019$.

\begin{abstract}
Crossword puzzle strategy is one strategy of active learning that involves all students to actively think by filling out crossword puzzles prepared by the teacher. So that students are expected to be more enthusiastic in participating in learning. This study aims to examine the effect of applying the crossword puzzle strategy to students' learning motivation in science learning. The research method used is a quantitative method, with the design of one-shoot case study. The population in this study were all students of class amounting to 21 students, and using saturated sampling in determining the sample. Data collection techniques used are structured observation, questionnaires, and documentation. Furthermore, the results of the research data were tested using regression tests. The results showed that the significance value of regression test was 0,000 . Because significant values is smaller than 0.05 and t count (4.316) is greater than t table (1.72913), it can be concluded that Ha is accepted and Ho is rejected. This means that the implementation of crossword puzzle strategy has a significant effect on students' learning motivation in science learning.
\end{abstract}

Keywords: crossword puzzle, students' learning motivation, science learning.

\begin{abstract}
Abstrak
Strategi crossword puzzle adalah salah satu strategi pembelajaran aktif yang melibatkan semua peserta didik untuk aktif berfikir dengan mengisi teka teki silang yang telah disiapkan oleh guru. Sehingga diharapkan peserta didik menjadi lebih antusias dalam mengikuti pembelajaran. Penelitian ini bertujuan untuk meneliti tentang pengaruh penerapan strategi crossword puzzle terhadap motivasi belajar siswa pada mata pelajaran IPA. Metode penelitian yang digunakan adalah metode
\end{abstract}


kuantitatif, dengan desain one-shoot case study. Populasi dalam penelitian ini adalah semua siswa kelas $\mathrm{V}$ yang berjumlah 21 siswa, dan menggunakan sampling jenuh dalam menentukan sampelnya. Teknik pengumpulan data yang digunakan adalah observasi, angket dan dokumentasi. Selanjutnya data hasil penelitian diuji menggunakan uji regresi. Hasil penelitian menunjukkan bahwa nilai signifikansi pada uji regresi sebesar 0,000. Karena nilai signifikansi lebih kecil dari 0,05 dan t hitung (4.316) lebih besar dari t tabel (1.72913), maka dapat disimpulkan bahwa Ha diterima dan Ho ditolak. Hal ini berarti bahwa penerapan strategi crossword puzzle berpengaruh signifikan terhadap motivasi belajar siswa pada mata pelajaran IPA.

Kata kunci: crossword puzzle, motivasi belajar siswa, pembelajaran IPA.

\section{INTRODUCTION}

One of the most important sciences learned and developed at the primary school level is Natural Sciences (IPA). According to Khisbiyah (2015) in his research mentioning that the aim of science subjects is to build a science literate society. What is meant by literacy is to be aware of the development of the world of information, technology, and human civilization as a whole in accordance with the progress of the world. People who are literate in science will not be afraid of change, because change is circumcision. But in reality, our society is still afraid of change. Change requires responsibility and risk. People who are aware of the development of the world will not remain silent, but always adjust to improve their abilities.

Yasmin, Ramdani, \& Azizah (2015) in their research revealed that the tendency of science learning in the present is that students only learn science as a product, memorize concepts, theories, and laws. This situation is exacerbated by test-oriented learning. As a result IPA as an attitude, process, and application is not present in learning. Learning is more teachercentered. Teachers only deliver science as products and learners memorize factual information. Students only study science in the lowest cognitive domain. Students are not accustomed to developing their thinking potential. Facts in the field show that many students tend to be lazy to think independently.

Therefore, Students' learning motivation in science learning becomes high, the teacher is required to think critically. To obtain these capabilities, learning must be conducted interactively, pleasantly, and supported by learning strategies that can motivate students to actively participate in learning. Thus, a teacher should be able to act as a facilitator in the learning process, where a teacher prepares all learning designs so that an active and creative learning process occurs. So that students are expected to be motivated to learn. According to Hamdu \& Agustina (2011), basically motivation is a conscious effort to move, direct, and maintain one's behavior so that he is compelled to act to do something so as to achieve certain results or goals. 
Retnasari, Maulana, \& Julia (2016) stated that motivation is very necessary in the learning process. Because someone who has no motivation in learning, then he will not be possible to do learning activities. For this reason, one of the supporting factors for student motivation is to optimize the learning strategy. In choosing a learning strategy, the teacher should be able to invite students to learn actively. When students are passive or only receive lessons from the teacher, there is a tendency to quickly forget the lessons given by the teacher (Zaini, 2008).

Based on Hernawati's reserach (2014), it states that learning motivation can affect student achievement in school. So, if students do not have the desire to learn, then the student's achievement will not be good. Meanwhile, according to Aritonang (2008) in his research mentioned that there are several factors that can cause student learning motivation to increase, including (1) teacher teaching methods, (2) teacher character, (3) calm and comfortable classroom atmosphere, and (4) learning facilities used. The definition of teacher teaching methods in the study is one of which is lack of variation or lack of interest in the learning strategies used by teachers, especially in science learning. Learning strategies must be done by teachers and students so that learning objectives can be achieved effectively and efficiently (Sanjaya, 2016). In student-centered learning, the teacher as a facilitator is required to be able to create a pleasant classroom atmosphere and active students in the learning process. Therefore a strategy is needed that can increase students' motivation to learn in science learning.

Today there are many innovative learning strategies that can make students active in learning. One strategy that can be used is the crossword puzzle strategy. One of the benefits of applying the crossword puzzle strategy is to foster a sense of enthusiasm and motivation of students in learning. Meanwhile, Rahmah (2016) in his research revealed that Crossword Puzzle is a media that allows students to think more creatively in entering letters so that they become words according to the length that has been available. The crossword puzzle strategy is very appropriate to make students active since the learning activities begin, especially for students who have the kinesthetic learning type. In this strategy students are invited to participate in all learning processes that involve mental and physical. With this students will feel a more pleasant atmosphere, so that learning outcomes can be maximized (Syahruddin, Fachruddin, \& Mardianto, 2017).

Mursilah (2017) in his research revealing that crossword puzzle is one method of active learning for students that involves all students to think when learning takes place to fill in crossword puzzles so students become more enthusiastic in participating in learning. Meanwhile, according to Anggraini, Sujadi, \& Widodo (2014) in his research revealed that the crossword puzzle strategy can increase students' motivation to study in class. In addition, the crossword 
puzzle strategy can also make students think critically which will have an impact on increasing student learning outcomes.

Madrasah Ibtidaiyah (MI) Salafiyah Cirebon City is one of the Madrasah Ibtidaiyah whose science learning is still monotonous and less varied. Based on the results of interviews with classroom teacher $\mathrm{V}$, it was revealed that during science learning, the teacher only used the lecture strategy. This is because the teacher does not have time to make or prepare innovative learning strategies. In addition, in the process of learning science, students are only emphasized to write and memorize it, so there is no attraction for students to learn. The learning process feels monotonous and students assume that science lessons are a difficult lesson. Therefore, in science learning, students look lazy. The unfavorable classroom atmosphere also causes student learning motivation to be low. Low motivation to learn results in the value of students still relatively low. Many students have a score below the minimum completeness criteria on each test, so they must do a remedial to improve the score.

From some of the explanations described above, there is a need for changes in science learning at MI Salafiyah. The crossword puzzle strategy can be an alternative to make science learning more enjoyable and can improve the activities of students in the classroom. If students feel happy, then student learning motivation also increases. This will have an impact on increasing student achievement in science lessons. This study aims to examine the effect of applying the crossword puzzle strategy to students' learning motivation in science subjects at MI Salafiyah Cirebon City.

\section{METHODS}

This research is quantitative research. The research design used in this study is OneShoot Case Study. In this study there was a group given treatment/treatment and then the results were observed. The population in this study were all students of class V at MI Salafiyah Cirebon City, amounting to 21 students. The sample used was saturated sampling, so that the entire population of 21 students became the study sample.

Data collection techniques used in this study were observation, questionnaire, and documentation. Questionnaires are used to obtain data about student responses to the use of crossword puzzle strategies and student motivation. The questionnaire used is a structured questionnaire, namely the researcher gives a set of written statements to the respondents arranged with several choices which according to them are exactly 20 statements, and using a Likert scale to calculate the questionnaire.

Meanwhile, data analysis technique used in this study is questionnaire data analysis and simple regression test. Analysis of questionnaire data is determined by formula: 


$$
\mathrm{P}=\frac{F}{N} \times 100 \% \quad \text { (Riduwan } \& \text { Sunarto, 2009) }
$$

Notes:

$\mathrm{P} \quad=$ Percentage of every possible answers

$\mathrm{F} \quad=$ Frequency of every possible answers

$\mathrm{N} \quad=$ Number of Respondent

$100 \%=$ Counting Standard (Constant Number)

Meanwhile, to find out whether or not there is an effect between the independent variables and the dependent variable, the researcher uses a simple regression test. The independent variable (free) is represented by $X$, while the dependent variable (bound) is represented by $\mathrm{Y}$. To test the simple regression equation, use the formula as shown in table 1 below:

Table 1. Simple Regression Test

\begin{tabular}{cccc}
\hline Formula & \multicolumn{1}{c}{ Symbol } & Notes \\
\hline & $\mathrm{Y}$ & & Dependent Variable \\
$\mathrm{Y}=\mathrm{a}+\mathrm{bX}$ & $\mathrm{X}$ & Independent Variable \\
& & $\mathrm{a}$ and $\mathrm{b}$ & Constant \\
\hline
\end{tabular}

where:

$$
\begin{aligned}
& \mathrm{b}=\frac{n \sum x y-\sum X \sum Y}{n \sum_{X} 2-\left(\sum X\right)^{2}} \\
& \mathrm{a}=\frac{\sum Y-b . \sum X}{n} \quad \text { (Suharsaputra, 2012) }
\end{aligned}
$$

\section{RESULTS AND DISCUSSION}

\section{Students' Response on te Application of Crossword Puzzle Strategy in Science Learning}

The results of student responses to the implementation of the crossword puzzle strategy in science learning can be presented in the following table 2:

Table 2. Recapitulation Data of Questionnaire

\begin{tabular}{llllll}
\hline Scale & $\begin{array}{l}\text { Strongly } \\
\text { Agree }\end{array}$ & Agree & Dissagree & $\begin{array}{l}\text { Strongly } \\
\text { Dissagree }\end{array}$ & Total \\
\hline $\begin{array}{l}\text { Students' } \\
\text { Questionnaire Score }\end{array}$ & 240 & 996 & 56 & 0 & 1292 \\
\hline \multicolumn{7}{r}{ Total Score } & & 1292 \\
\hline
\end{tabular}

Based on table 2, it can be seen that the number of student questionnaire scores obtained from 21 students with 20 items is 240 scores for the strongly agree category, 996 scores for the agreed category, 56 scores for the dissagree category, and 0 scores for the strongly disagree category. Thus, the total score of the questionnaire was 1,292 scores. The ideal score for this questionnaire is 20 statement items $x 21$ students $\mathrm{x} 4$ (maximum score for each item) $=1.680$. So 
that the percentage of student questionnaire scores towards the implementation of the crossword puzzle strategy is equal to:

$$
\frac{1292}{1680} \times 100 \%=76,9 \%
$$

The percentage of $76.9 \%$ belongs to the strong category, because it is in the percentage range of $60 \%-80 \%$. So it can be concluded that the application of the crossword puzzle strategy in science learning in Salafiyah MI was positively responded by students.

\section{Students' Learning Motivation on Science Learning Using Crossword Puzzle Strategy}

Student learning motivation in science learning for the topic "heat" is measured using a questionnaire. This questionnaire consists of 20 statements. Based on the results of the trials that have been done before, then there are 20 items that meet the valid criteria. The results of the student learning motivation questionnaire on science learning using the crossword puzzle strategy can be presented as shown in table 3 below:

Tabel 3. Students' Response on The Application of Crossword Puzzle Strategy

\begin{tabular}{lllllc}
\hline Scale & $\begin{array}{l}\text { Strongly } \\
\text { Agree }\end{array}$ & Agree & Dissagree & $\begin{array}{l}\text { Strongly } \\
\text { Dissagree }\end{array}$ & Total \\
\hline $\begin{array}{l}\text { Students' } \\
\text { Questionnaire Score }\end{array}$ & 744 & 594 & 60 & 5 & 1403 \\
\hline \multicolumn{7}{c}{ Total Score } & 1403 \\
\hline
\end{tabular}

Based on table 3, it can be seen that the number of student questionnaire scores obtained from 21 students with the number of statement items as many as 20 were 744 scores for the strongly agree category, 594 scores for the agreed category, 60 scores for the dissagree category, and 5 scores for the strongly disagree category. Thus, the total score of students' learning motivation questionnaire was 1,403 scores. The ideal score for this questionnaire is 20 statement items $\times 21$ students $\times 4$ (maximum score for each item) $=1.680$. So that the percentage of achievement of the questionnaire scores of students' learning motivation in science learning using the crossword puzzle strategy is equal to:

$$
\frac{1403}{1680} x 100 \%=84 \%
$$

The $84 \%$ percentage is categorized as very strong, because it is in the percentage range of $80 \%-100 \%$. So it can be concluded that the implementation of the crossword puzzle strategy can motivate students to study science material in MI/SD. 


\section{The Effect of Crossword Puzzle Application on Students' Learning Motivation in Science Learning}

To determine the effect of applying the crossword puzzle strategy to student learning motivation in science learning, researchers used a simple regression test analysis. This simple regression test consists of regression coefficient test and determination test. The results of a simple regression test analysis can be presented in the following table 4.

Table 4. Coefficients of Regression Test

\begin{tabular}{|c|c|c|c|c|c|}
\hline \multirow[t]{2}{*}{ Model } & \multicolumn{2}{|c|}{$\begin{array}{l}\text { Unstandardized } \\
\text { Coefficients }\end{array}$} & $\begin{array}{l}\text { Standardized } \\
\text { Coefficients }\end{array}$ & \multirow[t]{2}{*}{$\mathrm{T}$} & \multirow[t]{2}{*}{ Sig. } \\
\hline & B & Std. Error & Beta & & \\
\hline (Constant) & -5.347 & 15.942 & & -334 & .741 \\
\hline $\begin{array}{l}\text { Crossword Puzzle } \\
\text { Application }\end{array}$ & 1.118 & .259 & .704 & 4.316 & .000 \\
\hline
\end{tabular}

a. Dependent Variable: Learning Motivation

In table 4 , the regression coefficient test above shows that the constant value is $-5,347$ and the value of the implementation of the crossword puzzle strategy is 1,118. From this information, the regression equation can be obtained as follows:

$$
\mathrm{Y}=-5.347+1.118 \mathrm{X}
$$

It is known that the constant value is $-5,347$. This states that if there is no increase in the value or score of the variable implementation of the crossword puzzle strategy, then the learning motivation variable is students of $-5,347$. Meanwhile, the value of applying the crossword puzzle strategy is 0.865 . This states that every additional variable score occurs the implementation of the crossword puzzle strategy will be able to increase the increase in student learning motivation variables. In addition, based on the results of the regression test above it can be seen that the significance value is 0,000 . Because the significance value is smaller than 0.05 , Ho is rejected. This means that the implementation of the crossword puzzle strategy has a positive effect on students' learning motivation in science learning in class V of MI Salafiyah Cirebon City. To see how much influence the implementation of the crossword puzzle strategy can get student learning motivation in science learning can be presented in table 5 below:

Table 5. Determination Test/ R-Square Test

\begin{tabular}{rcccc}
\hline Model & R & R Square & Adjusted R Square & Std. Error of the Estimate \\
\hline 1 & $.704^{\mathrm{a}}$ & .495 & .474 & 9.905
\end{tabular}

a. Predictors: (Constant), crossword puzzle strategy 
In table 5, the determination test above shows that $\mathrm{R}$ Square is 0.495 (square of the correlation coefficient 0.704$)$. R Square is called the determinant coefficient which in this case is $49.5 \%$. From this value, it can be interpreted that $49.5 \%$ of students' learning motivation in science learning in Class V of MI Salafiyah is influenced by the implementation of the crossword puzzle strategy, while $50.5 \%$ is influenced by other factors.

From the results of the above research it is known that the application of the crossword puzzle strategy in science learning is positively responded by students, because the crossword puzzle strategy can increase students' motivation and activeness in science learning. This is in accordance with the results of research conducted by Radili (2013) that the results of student activities using the crossword puzzle strategy run quite effectively, students become more active in learning. Most students are motivated, interested, and actively participate in filling out and discussing the material contained in the crossword puzzle individually and working together to discuss it with their peers to exchange ideas. After all students have successfully completed the Crossword Puzzle, the teacher revisits and asks students for answers and opinions about the contents of the Crossword Puzzle so that students can better understand the material provided.

The results of this study are also in line with the research conducted by Rakhmadhani, Yamtinah, \& Utomo (2013) and Masita (2014) that the use of crossword puzzle strategies or crossword puzzles can increase student learning motivation. Learning strategies in the learning process can generate new desires / interests, generate motivation, stimulate learning, and bring psychological influence to students. The use of learning strategies at the learning orientation stage will greatly help the effectiveness of the learning process and the delivery of messages from the contents of the lessons provided. Desire or encouragement is called motivation. Motivation in this case includes two things, namely: Knowing what will be learned, and Understanding why it should be studied. Based on these two elements of motivation as a good starting point for learning. Because without motivation; not understanding what will be learned and not understanding why it needs to be learned) teaching and learning activities are difficult to succeed (Sardiman, 2012).

Susilo (2012) in his research revealed that student learning motivation in science learning can be seen from six aspects, namely showing interest in science lessons, happy looking for and solving science problems, resilient facing difficulties or not easily discouraged and not easily satisfied with achievement achieved in science lessons, diligently facing the task, preferring to work alone or not depend on others and show interest in various kinds of science problems.

In addition, the application of the crossword puzzle strategy also had a positive effect on students' learning motivation in science learning in class V at MI Salafiyah Cirebon City. This is reinforced by the results of Iskandar \& Rachmawati's research (2016) which states that 
crossword puzzle type active learning affects student learning motivation. Meanwhile, Febtrina, Suparman, \& Supriyadi (2014) in their research stated that the crossword puzzle strategy can influence students' motivation to interact in learning. So that it can increase activity and help students to build good interactions in the classroom. Students become bolder and enjoy interacting with each other in class.

\section{CONCLUSION}

Based on the description of the results of the research and discussion, it can be concluded that the application of the crossword puzzle strategy has a positive effect on students' learning motivation in science learning in the fifth grade of MI Salafiyah at $49.5 \%$. While the rest is influenced by other factors. Therefore, teachers are strongly advised to use the crossword puzzle strategy in science learning, because the crossword puzzle strategy is proven to increase student learning motivation. In addition, the crossword puzzle strategy can also increase student activity in the learning process. This certainly will have an impact on increasing student learning achievement in science learning.

\section{REFERENCES}

Anggraini, E. D., Sujadi, A., \& Widodo, S. A. (2014). Upaya Meningkatkan Motivasi dan Hasil Belajar Matematika melalui Model Pembelajaran Teams Games Tournaments dilengkapi Crossword Puzzle Siswa Kelas VIIIC SMP Negeri 3 Sawangan Magelang. UNION, 2(1), $1-8$.

Aritonang, K. (2008). Minat dan Motivasi dalam Meningkatkan Hasil Belajar Siswa. Jurnal Pendidikan Penabur, 7(10), 11-21.

Febtrina, R., Suparman, U., \& Supriyadi, D. (2014). The Use of Crossword Puzzle on Students' Interaction in Learning Vocabulary. U-JET, 3(6), 1-15.

Hamdu, G., \& Agustina, L. (2011). Pengaruh Motivasi Siswa terhadap Prestasi Belajar IPA di Sekolah Dasar (Studi Kasus terhadap Siswa Kelas IV SDN Tarumanagara Kecamatan Tawang Kota Tasikmalaya). Jurnal Penelitian Pendidikan, 12(1), 81-86.

Hernawati, I. P. (2014). Pengaruh Motivasi Belajar terhadap Prestasi Belajar di Sekolah Gratis SD Negeri Pakisjajar 02 Kabupaten Malang. PSIKOVIDYA, 18(2), 132-151.

Iskandar, R., \& Rachmawati, D. R. (2016). Tanggapan Siswa terhadap Strategi Active Learning Tipe Crossword Puzzle Hubungannya dengan Motivasi Belajar Siswa pada Mata Pelajaran IPS Konsep Perkembangan Teknologi Komunikasi. Jurnal Penelitian Dasar, 7(1), 139-149.

Khisbiyah, I. (2015). Pengaruh Media Film Animasi terhadap Motivasi Belajar Siswa Mata Pelajaran IPA (Studi Penelitian MI AN-NUR Kota Cirebon). Al Ibtida: Jurnal Pendidikan Guru MI, 2(2), 1-15. 
Masita, A. (2014). Meningkatkan Hasil Pembelajaran IPA melalui Strategi Pembelajaran Induktif Siswa Kelas IV SDN 6 Watuoge. Jurnal Kreatif Tadulako, 5(5), 1-15.

Mursilah. (2017). Penerapan Metode Crossword Puzzle dalam Meningkatkan Hasil Belajar IPS Kelas XII SMK Nurul Huda. UNILTY, 1(1), 37-47.

Radili, L. (2013). Pengaruh Penggunaan Crossword Puzzle terhadap Hasil Belajar Siswa pada Mata Pelajaran Teknologi Informasi dan Komunikasi. E-Tech, 1(1), 1-12.

Rahmah, L. A. (2016). Penerapan Media Pembelajaran Crossword Puzzle untuk Meningkatkan Hasil Belajar Ekonomi pada Kompetensi Dasar Konsep dan Pengelolaan Koperasi Kelas X IIS 2 di SMA Negeri 1 Driyorejo Gresik. Junal Pendidikan Ekonomi (JUPE), 4(3), 110.

Rakhmadhani, N., Yamtinah, S., \& Utomo, S. B. (2013). Pengaruh Penggunaan Metode Team Games Tournaments Berbantuan Media Teka Teki Silang dan Ular Tangga dengan Motivasi Belajar terhadap Prestasi siswa pada Materi Koloid Kelas XI SMA Negeri 1 Simo Tahun Pelajaran 2011/2012 . Jurnal Pendidikan Kimia (JPK), 2(4), 1-8.

Retnasari, R., Maulana, \& Julia. (2016). Pengaruh Pendekatan Kontekstual terhadap Kemampuan Koneksi Matematis dan Motivasi Belajar Siswa Sekolah Dasar Kelas IV pada Materi Bilangan Bulat. Jurnal Pena Ilmiah, 1(1), 1-10.

Riduwan, \& Sunarto. (2009). Pengantar Statistika. Bandung: Alfabeta.

Sanjaya, W. (2016). Strategi Pembelajaran Berorientasi Standar Proses Pendidikan. Jakarta: Kencana Prenada Media Grup.

Sardiman. (2012). Interaksi dan Motivasi Belajar Mengajar. Jakarta: Kencana Prenada Kencana.

Suharsaputra, U. (2012). Metode Penelitian Kuantitatif, Kualitatif, dan Tindakan. Bandung: PT. Revika Aditama.

Susilo, A. (2012). Pengembangan Model Pembelajaran IPA Berbasis Masalah untuk Meningkatkan Motivasi Belajar dan Berpikir Kritis Siswa SMP . Journal of Primary Educational, 1(1), 57-63.

Syahruddin, Fachruddin, \& Mardianto. (2017). Pengaruh Strategi Everyone Is ATeacher Here (ETH), Contextual Teaching and Learning (CTL), dan Crossword Puzzle (CWP) serta Motivasi Belajar terhadap Hasil Belajar Siswa Pada Mata Pelajaran Bahasa Arab di MTs. Darul Falah Aek Songsongan . ITTIHAD, 1(2), 131-154.

Yasmin, N., Ramdani, A., \& Azizah, A. (2015). Pengaruh Metode Inkuiri Terbimbing terhadap Ketrampilan Proses Sains dan Hasil Belajar Biologi Siswa Kelas VIII di SMPN 3 Gunungsari Tahun Ajaran 2013/2014. J. Pijar MIPA, X(1), 69-75.

Zaini, H. (2008). Strategi Pembelajaran Aktif. Yogyakarta: Pustaka Insan Madani. 